\title{
Patient Decision Making in the Choice of a Referral Hospital in Hospital of Subulussalam City in 2018
}

\author{
Siti Latifah Hanum ${ }^{1}$, Destanul Aulia ${ }^{2}$, Kintoko Rochadi ${ }^{2}$ \\ ${ }^{1}$ Master Student in Faculty of Public Health, Universitas Sumatera Utara, Medan, Indonesia \\ ${ }^{2}$ Lecturer in Faculty of Public Health, Universitas Sumatera Utara, Medan, Medan, Indonesia \\ Email: tabahjuang21@gmail.com
}

\begin{abstract}
:
The choice of referral hospital from Hospital of Subulussalam City based on a preliminary survey is varies. Inpatients are referred to Class A hospitals are on average $65 \%$, Class B hospitals are $30 \%$, and Class $C$ hospitals are 5\%, while outpatients are referred to Class $A$ hospitals are on average $49 \%$, Class B hospitals are $28 \%$, class C hospitals are $23 \%$. This type of research is qualitative with a phenomenological approach obtained by conducting in-depth interviews with 13 informants consisting of 3 specialist doctors, 3 general practitioners, 3 patients, 3 patient's family and 1 BPJS verifier in Hospital of Subulussalam City. The study was conducted from February to October 2018. The results showed that during the referral hospital decision-making process there was an interaction between the doctor, the patient and the patient's family, the final decision was on the patient and bearing down the consequences if the hospital's choice was not recommended by the doctor. The determinants of decision making for referral hospitals consist of perceived quality in the form of referral hospitals accepting patients referred from Hospital of Subulussalam City, emergency conditions for patients by choosing the closest hospital, facilities in the form of supporting tests and complete medical devices and additional facilities, the availability of specialist doctors and subspecialty according to the patient's condition, geographical constraints due to the long distance to the referral hospital, references from doctors to patients and vice versa, learning in the form of doctor and patient experience in the previous referral process, not all doctors consider peer relations to be a determinant of choosing a referral hospital due to the BPJS system, social factors in the form of a family in the area of a referral hospital, the same religion and culture as a patient in a referral hospital area make the patient feel comfortable. Suggestions in this study is the management of Hospital of Subulussalam City to confirm and coordinate the referral hospital and make a referral MOU.
\end{abstract}

Keywords:

decision-making; choice; hospital; referral

\section{Introduction}

The health insurance system that has been programmed by the government aims to encourage the overall and standardized improvement of health services to the Indonesian people by using a tiered referral system that is regulated in the Minister of Health Regulation No. 001 of 2012. The referral system is the organization of health services that regulates the delegation of duties and responsibilities vertical and horizontal reciprocal health services.

Hospital of Subulussalam City is the only hospital in Subulussalam City with the status of Subulussalam City Government, Aceh Province. The geographical location of Subulussalam City is the border area between Aceh Province and North Sumatra where the distance to the capital city of North Sumatra Province, Medan City is closer than the distance from the capital of Aceh Province, Namely Banda Aceh City. From Subulussalam City to Medan City takes 7 hours while to Banda Aceh takes 12 hours. 
Based on the Decree of the Minister of Health number HK.02.03 / I / 0429/2015 concerning the determination of Subulussalam City Hospital Class C, with 200 beds in total. The availability of Specialist Doctors is very limited which consists of only five specialist doctors, namely specialists in internal medicine, surgery, obstetrics, children and anesthetics where each section amounts to 1 person.

Preliminary survey results at Subulussalam City Hospital in November 2017 to January 2018 showed that about 99\% of patients at the Subulussalam City Hospital were BPJS patients. Destination hospitals that are often referred to include: Adam Malik Hospital, Zainal Abidin Hospital, Dr. Pirngadi Hospital, Murni Teguh Hospital and Dr. H. Yulidin Away Hospital, and several Special hospitals such as the Banda Aceh Mental Hospital and Sumatra Eye Center Hospital.

Referral for Inpatient Patients based on the class of the referenced hospital, the objective data obtained for class A referral hospitals is $65 \%$, category B hospitals are $30 \%$, and category C hospitals are $5 \%$. For the chosen category of referral hospitals, the regional referral hospitals in South Aceh (Yuliddin Away Hospital) were only 16\% while other hospitals were $84 \%$.

For outpatients referral hospital options are more varied than inpatient referral patients. Outpatients receiving outpatient care at Subulussalam City Hospital chose a referral hospital to a regional hospital (Yuliddin Away Hospital) by only 1.6\% while the referral destination to other hospitals was $99.4 \%$. For the category of referral hospital based on class, referral to category A hospital is $49 \%$, category B hospital is $28 \%$, to category C hospital is $23 \%$. The data shows that the choice of referral hospitals from the Subulussalam City Hospital varies and the number of referral destinations to category A hospitals exceeds those referenced to category B.

There are some exceptions in the patient referral rules, among others, by considering the condition of health services, namely in terms of the availability of health facilities, the equipment side such as the availability of tools and medicines, the availability of medical personnel, exceptions due to emergency conditions, disaster conditions geographical considerations, and the specificity of the problem patient health, (Ministry of Health, 2014).

A patient or patient's family chooses a referral hospital based on recommendations from a lower health facility, or location, completeness of health facilities, service costs, or the level of emergency of the patient. In carrying out the mapping of the referral area, the patient / family desires factors of the patient in choosing the referral destination need to be taken into consideration (Syafrudin in Khoirunnisa, 2016)

Research on hospital choices has been studied both abroad and in Indonesia. One study abroad on patient preference is a study by Rajkumar Grinhari Singh, Dr. Md. Kheiruddin Shah, (2013) about Customers' Preference for Private Hospital Selecting: A Study in Minipur shows from several factors the attributes of choosing a hospital, namely distance, comfort of transportation, cost, infrastructure, availability of specialist doctors, emergency patients, family advice, doctor's recommendations, Safety and comfort, the influence of the media, and the availability of facilities, the highest proportion is the availability of specialist doctors followed by infrastructure and comfort and safety. In Indonesia, one of the related studies is one of the studies by Anggraheni (2013) about the factors that influence community decision making to choose health services, showing that there is an influence on the quality of services, treatment costs on the selection of health services in PKU Muhamadiyah hospitals while for service facilities. there is influence. 
Based on preliminary survey data variations in the choice of referral hospitals from Hospital of Subulussalam City and there are several previous studies on hospital choice factors, researchers are interested in examining the decision making of patients in the choice of referral hospitals.

\section{Research Method}

This type of research used in this study is qualitative with a phenemological approach. Research Location in Hospital of Subulussalam City, Aceh Province. The time of the study was carried out in February 2018 until October 2018 (starting from the survey research to the presentation of research results). Conducted with in-depth interviews with 13 informants consisting of 3 specialist doctors, 3 general practitioners, 3 patients, patient's family and 1 BPJS Health verifier.

\section{Result and Discussion}

\subsection{Decision Making Process of Referral Hospital Choices at Hospital Subulussalam City}

From interviews with several research informants informing doctors that in determining the decision making process of referral hospital selection through a patient examination process, it was decided that the patient should be referred because of the patient's needs in the form of supporting examinations, further actions and specialist doctors that are not in the Subulussalam City Hospital .

Then the process of interaction occurs between the patient, the doctor and the patient's family. In the initial stage the referring doctor explains to the patient and the patient's family about the patient must be referred to and explains some referral hospital options in the form of advantages and disadvantages to the patient and the patient's family and the final determination of the referral hospital's decision is on the patient.

The doctor recommends a referral hospital for patients with emergency conditions, while patients who are not emergency patients can provide input on the desired referral hospital. Officials of Subulussalam City Hospital try to confirm the referral hospital whether they are willing to accept referral patients in the process of determining the referral hospital and if they do not accept with full reason then the doctor offers another referral hospital and with the patient's consent.

The process of interaction between patients, doctors and patients' families in decision making in choosing a referral hospital in Subulussalam City Hospital according to Andhy (2016) which states that the relationship between doctors and patients is essentially not possible without going through communicative interactions where both parties participate in each other (reciprocity). Interaction is the occurrence of a reciprocal relationship between the communicator and the communicant whether it is individual, group or community. Interaction is very helpful for patients in the healing process and treatment where both the doctor and the patient will give information to one another so that not only doctors are active but patients are also expected to be active.

The decision to obtain the consent of the patient and family of the patient is in accordance with Permenkes RI No. 001 of 2012 concerning the Individual Health Service Referral System, referrals are given with the following conditions: Referrals must obtain approval from the patient and / or his family and consent is given after the patient and / or family get an 
explanation from the authorized health personnel. Interaction between doctors and patients is an activity that is carried out professionally, according to ethics and community values and in accordance with applicable standard procedures.

\subsection{The Determinants of Patient Decision Making in the Choice of Referral Hospitals at Subulussalam City Hospital}

Determinant is a determinant factor behind the behavior. According to Philip Kotler and Kevin Lane Keller said consumer behavior is the study of how individuals, groups and organizations choose, buy, use and how goods, services, ideas, or experiences to satisfy their needs and desires.

There are various determinants why someone buys a certain product to meet their needs and desires. Including with a patient or a doctor in terms of choosing hospital services therefore the hospital understands consumer behavior. From interviews with research informants, the determinants of doctors, patients and family of patients in Subulussalam City Hospital in choosing a referral hospital are as follows:

\section{a. Hospital Quality Perception}

From the interview with the referring doctor informant explained that the service quality factor of the referred hospital is accepting patients for treatment and not neglecting the patient to be the doctor's determinant in determining the choice of referral hospital to the next patient, even according to the informant as the referring doctor trying not to choose the referral hospital again. Perception does not only depend on physical stimuli, but also on stimuli related to the environment and the individual's condition. The process of evaluating the surrounding environment will be taken into consideration by someone choosing.

The same was stated by patient informants and patients' families that the quality of the hospital was a consideration for choosing a referral hospital. Patient and family percentages are due to the quality of the hospital in which they are intended to receive patients for treatment, even the patient's perception of hospital quality is still good for referral hospitals that have a long response time but patients are still accepted.

This is consistent with research conducted by Haryanto and Ollivia (2013) which shows that perceptions of hospital service facilities are not the cause for someone to go to Singapore for treatment, but the deciding factors are the quality of medical personnel and the quality of hospital services. Likewise, research conducted by Aggrhaeni (2013) shows that there is an effect of service quality, medical costs on health service selection, Magdalena (2017) where the results of the study indicate that the majority or families of patients in Bangka Belitung choose the hospital that has the most health services well.

Overseas research related to hospital selection because hospital quality is carried out by Gutacker, Nils, Siciliani, Luigi, Moscelli, Giuseppe (2016) shows that patients prefer hospitals with good quality that is by reporting in full the progress of their health, even though they have to travel long distances to reach the hospital they want.

\section{b. Emergencies}

The results of interviews with doctor informants who refer that doctors choose a referral hospital with consideration of the patient's emergency condition, if the patient's condition is an emergency then the doctor has not many referral hospital options to consider, the most important is patient safety, the doctor chooses a referral hospital close to the available facilities 
and doctor according to patient care needs. Emergency conditions or emergency conditions are conditions where patients need immediate help, which is fast, precise, and careful to prevent death and disability (Time saving Is the life saving). This research is in line with research conducted by Rajkumar Grinhari Singh, Dr. Md. Kheiruddin Shah (2013) showed that the emergency factor of patients became one of the patients choosing a private hospital.

\section{c. Amenities}

Availability of services that make it easy for patients to obtain or consume the necessary services such as laboratories, radiology examinations, medicines and medical devices for diagnostic and treatment purposes directly and indirectly affect the hospital visit (Indriyani, 2013).

The results of the interview with the referring doctor's informant indicated that the doctor chose a referral hospital because of facilities such as supporting examinations, medicines and also the referral hospital's medical equipment. Patients were referred from Subulussalam City Hospital because they needed supporting examinations and the use of sophisticated medical devices that were not available in Subulussalam City Hospital so that patients were referred to the referral hospital with available facilities according to the conditions needed by the patient, besides that there were complementary facilities available at home referral hospital such as a halfway house is a factor doctors choose a referral hospital.

This study is in line with the research of Khudoiri (2013). The completeness of hospital facilities determines the assessment of patient satisfaction and also includes facilities and infrastructure, parking lots, comfortable waiting rooms and inpatient rooms. Although this is not vital in determining the assessment of client satisfaction, hospitals need to pay attention to hospital facilities in developing strategies to attract consumers.

This is different from research conducted by Haryanto and Ollivia, (20014) showing that the perception of hospital service facilities is not the reason someone goes to Singapore for treatment, but the determining factors are the quality of medical personnel and the quality of hospital services. A similar study conducted by Aggrhaeni (2013) showed that there was no influence of facilities on the selection of health services in PKU Muhammadiyah Boyolali hospital.

\section{d. Expertise (Specialist Doctor)}

The availability of medical specialists and sub-specialists in the hospital due to the limited number and also the absence in the hospital is the reason patients are referred to the referral hospital, this is also a factor in patients being referred from the Subulussalam City Hospital. Based on the data of health workers in Subulussalam City Hospital that have 1 basic specialist doctor in each field and 1 medical support specialist, namely 1 anesthetist, so that if a specialist is out of town due to training there is no substitute for duty. Subulussalam City Hospital type C class hospital, according to the Regulation of the Minister of Health of the Republic of Indonesia Number 56 Year 2014 the standard of specialist doctors for C class hospitals is 2 doctors for each type of basic specialist medical service.

The interview results of the referring doctor and patient informants indicate that the availability of specialist doctors is a consideration for choosing a referral hospital, if the hospital is close but confirmed that there is no specialist doctor then the informant chooses another referral hospital. This is the same as the results of research conducted by Rajkumar Grinhari Singh, Dr. Md. Kheiruddin Shah (2013) in Miniapur which shows the highest proportion is the availability of specialist doctors to be a factor in choosing a hospital. 


\section{e. Geographical}

Based on an interview with one of the informants as referring, distance factor becomes a choice depending on the patient's condition, if the emergency and a nearby hospital can receive a referral then a nearby hospital is chosen. Often location is a crucial factor in determining the success of a service sale. This is in line with Hartono's research that location is one of the considerations of consumers in determining their choice of a service. Engel, Blackwell. Miniard said that the distance of the location of the hospital is a determinant of the decision in choosing the place of sale. The distance between the location of sales and potential buyers is also a concern for marketers (Fauzia, 2014).

\section{f. Peer Relations}

From the interviews of several doctor's informants who referred only one informant who thought that peer relations became a consideration factor in choosing a referral hospital because it made it easier for doctors to know their history and previous handling and for referring doctors to know the progress of patient's medication when the patient was re-controlled at Subulussalam City Hospital. While some other doctor informants who refer consider the relationship factor not to be a determinant of the doctor in choosing a referral hospital due to the JKN system even though the doctor from the referral hospital has an acquaintance of the doctor of the referral hospital for referral, it cannot be ascertained that the referred patient is accepted by the destination hospital because it determines is hospital management.

\section{g. Reference}

Reference becomes the determinant in choosing a referral hospital not only for a patient to receive a reference from a doctor but a doctor also receives a reference from a patient who has been referred to a particular referral hospital. Based on the interview, it shows that the informant as a referring doctor is very considerate of patient testimonials that have been referred as reference material for doctors in choosing a referral hospital for other patients. According to Kotler, a person's reference group consists of all groups that have a direct or indirect influence on a person's attitude or behavior.

\section{h. Learning}

The results of interviews from referring doctor informants who said the experience factor was taken into consideration in choosing a referral hospital, both own experience when referring patients and based on the testimonies of patients who had been referred. The experience of the doctor of Subulussalam City Hospital as a referring doctor confirmed the referral hospital in Medan before referring the patient but always got an answer from the referral hospital that the room was full, according to one informant once referring the patient to use the ambulance of the Subulussalam City Hospital but when he got in referral hospitals patients are rejected, so they must be referred to other hospitals with ambulance costs borne by the patient because the BPJS health only pays the ambulance referral money to the hospital that refers to the first referral hospital.

\section{i. Social}

From the interview results the doctor's informant who referred gave information that patients often asked the doctor to choose a particular referral hospital due to social factors such as the presence of a family in the area of the referral hospital. This is in line with the results of interviews with the patient's informant and patient's family, which shows that the informant chose a referral hospital due to the presence of a family in the hospital's destination. The suggestion from the family is a factor in the choice of a referral hospital. Besides that, the reason is also due to the presence of a family in the destination hospital area, moreover it is supported 
by the availability of specialist doctors in the hospital so that patients can be operated. According to Kotler, social class is a relatively homogeneous and long-lasting group in a society that is arranged in a hierarchical order and members in each level have the same values, interests or interests, and behavior (Setiadi, 2015).

\section{j. Religion and culture}

From patient and family interviews, patients chose a referral hospital because of religious and cultural factors, the majority of cultural and religious factors in the referral hospital were taken into consideration, because the informants felt uncomfortable and unfamiliar in the majority of different religious and cultural environments. So the informant chose a referral hospital that was religious and the culture is the same as them. Culture is the most fundamental cause of one's desires and behavior. Culture is a collection of basic values, perceptions, desires and behaviors that are learned by a community member from family and other important institutions. Sub culture includes all ways or patterns of thinking, feeling and acting that humans as members of society (Setiadi, 2015).

\section{Conclusion}

During the referral hospital decision-making process there was an interaction between the doctor, the patient and the patient's family, the final decision was on the patient and bearing down the consequences if the hospital's choice was not recommended by the doctor. The determinants of decision making for referral hospitals consist of perceived quality in the form of referral hospitals accepting patients referred from Hospital of Subulussalam City, emergency conditions for patients by choosing the closest hospital, facilities in the form of supporting tests and complete medical devices and additional facilities, the availability of specialist doctors and subspecialty according to the patient's condition, geographical constraints due to the long distance to the referral hospital, references from doctors to patients and vice versa, learning in the form of doctor and patient experience in the previous referral process, not all doctors consider peer relations to be a determinant of choosing a referral hospital due to the BPJS system, social factors in the form of a family in the area of a referral hospital, the same religion and culture as a patient in a referral hospital area make the patient feel comfortable. Suggestions in this study is the management of Hospital of Subulussalam City to confirm and coordinate the referral hospital and make a referral MOU.

\section{References}

Adawiyah, R. (2017). Analisis rujukan puskesmas Penyabungan Jae Kabupaten Mandailing Natal dalam Era jaminan kesehatan nasional tahun 2017. (Skripsi). Medan : Universitas Sumatera Utara

Alamsyah, 2017. Faktor-faktor yang Mempengaruhi pasien dalam pemanfaatan layanan rawat jalan di Rumah Sakit Universitas Hasanuddin. (Skripsi). Makassar : Universitas Hasanuddin

Alaszewki, A, dkk. (Eds) 2000. Managing risk in community practise, London : Harcourt Publisher Limited

Anggraeni, N. V. (2013). Faktor-faktor yang mempengaruhi pengambilan keputusan masyarakat untuk memilih jasa pelayanan kesehatan di rumah sakit PKU Muhammadiyah Simo Kabupaten Boyolali. (Skripsi). Surakarta : Fakultas Ilmu Kesehatan Universitas Muhaadiyah Surakarta.

BPJS. 2014. Panduan praktis sistem rujukan berjenjang. 2014, Jakarta: Badan Penyelenggara Jaminan Sosial. 
Creswell, J. W. (2016). Reseach design : pendekatan metode kualitatif, kuantitatif dan campuran. Yogyakarta : Pustaka Pelajar

Dumpapa, R. K. 2013. Hubungan lokasi, bsiaya, personil dan informasi rumah sakit dengan keputusan memilih rawat inap di rumah sakit Umum daerah Bitung. Diakses 25 April 2018 repo.unsrat.ac.id/178/1/Grace_Korompis_Hubungan_Lokasi.pdf

Gutacker, Nils, Siciliani, Luigi, Moscelli, Giuseppe, 2016. Choice of hospital: Which type of quality matters. Diakses 25 April2018https://www.ncbi.nlm.nih.gov/pmc/articles/PMC5138156/

Haryanto, J. O. O. (2014). Pengaruh faktor pelayanan rumah sakit, tenaga medis, dan kualitas pelayanan rumah sakit terhadap intensi pasien indonesia untuk berobatdi singapura. jkii No. 2 Vo. 14, Agustus 2009

Juwita, S. (2015). Pengambilan keputusan rujukan ke rumah sakit pada ibu hamil berisiko tinggi dalam perspektif gender. (Tesis) Surakarta : Universitas Sebelas Maret.

Kasmadi, (2015). Analisis manajemen rujukan berjenjang pelayanan kesehatan jaminan kesehatan nasional (JKN) di rumah sakit umum daerah TGK Abdullah Syafii Kabupaten Pidie Aceh. (Tesis). Medan: Universitas Sumatera Utara.

Kementerian Kesehatan RI, (2013). Buku pegangan sosialisasi jamninan Kesehatan Nasional (JKN) dalam sistem jaminan sosial nasional. 2013, Jakarta: Kementerian Kesehatan Republik Indonesia

Kementerian Kesehatan RI, (2014). Buku saku FAQ (frequently ask question) BPJS Kesehatan. 2014, Jakarta: Kementerian Kesehatan Republik Indonesia

Kementerian Kesehatan RI, (2014). Buku panduan praktis sistem rujukan. 2014, Jakarta: Kementerian Kesehatan Republik Indonesia

Kementerian Kesehatan RI, (2014). Buku info BPJS Edisi VI "ikuti prosedurnya, dapatkan manfaatnya, menggali rujukan berjenjang". 2014, Jakarta: Kementerian Kesehatan Republik Indonesia

Kementerian Kesehatan RI, (2012). Peraturan Menteri Kesehatan No.001 Tahun 2012 tentang Sistem Rujukan Pelayanan Kesehatan Perorangan. 2012, Jakarta: Kementerian Kesehatan Republik Indonesia

Kementerian Kesehatan RI, (2012). Peraturan menteri kesehatan No.72 Tahun 2012 tentang Sistem Kesehatan Nasional. Jakarta : Kementerian Kesehatan Republik Indonesia

Kementerian Kesehatan RI, (2013). Peraturan Menteri Kesehatan No.71 Tahun 2013 tentang Pelayanan Kesehatan pada Jaminan Kesehatan Nasional. Jakarta : Kementerian Kesehatan Republik Indonesia

Kementerian Kesehatan RI, (2014). Peraturan Menteri Kesehatan No.27 Tahun 2014 tentang Pedoman Pelaksanaan Program Jaminan Kesehatan Nasional. Jakarta : Kementerian Kesehatan Republik Indonesia

Kementerian Kesehatan RI, 2014. Peraturan Menteri Kesehatan No.56 Tahun 2014 tentang Klasifikasi dan Perizinan Rumah Sakit. Jakarta : Kementerian Kesehatan Republik Indonesia

Kementerian Kesehatan RI, (2014). Keputusan Menteri Kesehatan No. 391 Tahun 2014 tentang Pedoman Penetapan Rumah Sakit Rujukan Regional. Jakarta : Kementerian Kesehatan Republik Indonesia

Khoirunisa, S. D, (2016). Analisis sistem rujukan berjenjang dalam pelayanan kesehatan jaminan kesehatan nasional (JKN) Kota Subulussalam Tahun 2016. Skripsi Universitas Sumatera Utara

Magdalena, H, (2017). Analisis faktor-faktor pendukung pengambilan keputusan memilih rumah sakit rujukan di Bangka Belitung Dengan Analitycal Hierarchy bvvProcess (Fountain of Informatics Journal). Dipublikasikan pada November 2017, Diakses pada 31 Maret 2018

Manik, M, (2015). Analisis manajemen rujukan pasien jaminan kesehatan nasional (JKN) di 
rumah sakit umum daerah (RSUD) Kota Pinang Kabupaten Labuhan Batu Selatan. Medan: Tesis Universitas Sumatera Utara

Marquish, B.L, Huston C.J, (1996). Management decision making for nurse. Philadelphia : Lippincott.

Miles, Mathew B. Michael Huberman, (1992). Analisis Data Kualitatif. Terjemahan dari analyzing Qualitatif Data. Jakarta: UI Press

Peraturan Presiden, 2016. Peraturan Presiden Republik Indonesia Nomor 19 Tahun 2016 tentang Jaminan Kesehatan. Jakarta

Peraturan Gubernur, 2015. Peraturan Gubernur Aceh Nomor 9 Tahun 2015 tentang Pedoman Penetapan dan Pelaksanaan Rumah Sakit Rujukan Regional di Aceh. Aceh

Fauzia, Rahmania, 2014. Faktor-faktor yang Berhubungan dengan Keputusan Pemilihan Tempat Persalinan Pasien poliklinik Kandungan dan kebidanan di rumah sakit ibu dan anak Kemang Medical Care Tahun 2014. (Skripsi) Jakarta : Universitas Islam Negeri Syarif Hidayatullah

RSUD Kota Subulussalam. 2017. Profil Kesehatan Rumah Sakit RSUD Kota Subulussalam. Subulussalam: RSUD Kota Subulussalam

RSUD Kota Subulussalam. 2018. data rekam medis RSUD Kota Subulussalam Tahun 2018. Subulussalam: RSUD Kota Subulussalam

Setiadi, (2015). Edisi terbaru perilaku konsumen. Bogor, Kencana.

Sugiyono, (2013). Metode penelitian kuantitatif kualitatif dan R\&D. Bandung : Alfabeta

Sumantri, (2013). Metodologi penelitian kesehatan. Jakarta: Kencana

Undang-Undang Nomor 36 Tahun 2009 tentang Kesehatan 